\title{
Improved mycelia and polysaccharide production of Grifola frondosa by controlling morphology with microparticle Talc
}

\author{
Ting-Lei Tao ${ }^{1}$, Feng-Jie Cui ${ }^{1,3^{*}}$ D, Xiao-Xiao Chen ${ }^{1}$, Wen-Jing Sun ${ }^{1,3}$, Da-Ming Huang ${ }^{1}$, Jinsong Zhang ${ }^{2}$, \\ Yan Yang ${ }^{2}$, Di Wu ${ }^{2}$ and Wei-Min Liu ${ }^{1}$
}

\begin{abstract}
Background: Mushroom showed pellet, clump and/or filamentous mycelial morphologies during submerged fermentation. Addition of microparticles including Talc (magnesium silicate), aluminum oxide and titanium oxide could control mycelial morphologies to improve mycelia growth and secondary metabolites production. Here, effect of microparticle Talc $(45 \mu \mathrm{m})$ addition on the mycelial morphology, fermentation performance, monosaccharide compositions of polysaccharides and enzymes activities associated with polysaccharide synthesis in G. frondosa was well investigated to find a clue of the relationship between polysaccharide biosynthesis and morphological changes.

Results: Addition of Talc decreased the diameter of the pellets and increased the percentage of S-fraction mycelia. Talc gave the maximum mycelial biomass of $19.25 \mathrm{~g} / \mathrm{L}$ and exo-polysaccharide of $3.12 \mathrm{~g} / \mathrm{L}$ at $6.0 \mathrm{~g} / \mathrm{L}$ of Talc, and mycelial polysaccharide of $0.24 \mathrm{~g} / \mathrm{g}$ at $3.0 \mathrm{~g} / \mathrm{L}$ of Talc. Talc altered the monosaccharide compositions/percentages in G. frondosa mycelial polysaccharide with highest mannose percentage of $62.76 \%$ and lowest glucose percentage of $15.22 \%$ followed with the corresponding changes of polysaccharide-synthesis associated enzymes including lowest UDP-glucose pyrophosphorylase (UGP) activity of $91.18 \mathrm{mU} / \mathrm{mg}$ and highest UDP-glucose dehydrogenase (UGDG) and GDP-mannose pyrophosphorylase (GMPPB) activities of $81.45 \mathrm{mU} / \mathrm{mg}$ and $93.15 \mathrm{mU} / \mathrm{mg}$.
\end{abstract}

Conclusion: Our findings revealed that the presence of Talc significantly changed the polysaccharide production and sugar compositions/percentages in mycelial and exo-polysaccharides by affecting mycelial morphology and polysaccharide-biosynthesis related enzymes activities of $G$. frondosa.

Keywords: Grifola frondosa, Microparticle Talc, Mycelial morphology, Polysaccharide biosynthesis, Enzyme activities

\section{Background}

Mushrooms provide tasty and nutritional benefits with the expanded usage to pharmaceutical and cosmeceutical areas [1, 2]. Mushroom polysaccharides are regarded as the biological macromolecules with immunomodulatory, antitumor, anti-inflammatory and hypoglycemic, and hepatoprotective activities [3]. Generally, mushroom polysaccharides are prepared from the fruiting bodies, mycelia and/or submerged fermentation broth [4-6]. In most cases, mushroom fruiting bodies grow on the solid substrates

\footnotetext{
*Correspondence: fengjiecui@ujs.edu.cn; fengjiecui@163.com

${ }^{3}$ Jiangxi Provincial Engineering and Technology Center for Food Additives

Bio-production, Dexing 334221, People's Republic of China

Full list of author information is available at the end of the article
}

including crop by-products such as cottonseed hulls [7] and corn distiller's waste $[8,9]$ for 2-4 month cultivation. Mycelia or fermentation broth is a promising alternative to meet the increasing demand on the commercial mushroom products with shorter culture period, consistent product quality and independent of seasonality $[10,11]$.

Similar to filamentous microorganisms, the mushroom mycelia showed pellet, clump and/or filamentous morphologies during fermentation [12, 13]. The strain physiology, culture conditions and process parameters changed morphological appearances, which further influenced the fermentation performance including nutrient consumption, oxygen uptake rate, mycelia growth and metabolites production [14]. For example, the medicinal 
mushroom Ganoderma lucidum had a twofold increase of the maximum biomass productivity with the dispersed morphology under controlled DO conditions [15]. Our previous data also revealed that high aeration (0.75$1.0 \mathrm{vvm})$ and low agitation $(90 \mathrm{rpm})$ resulted in filamentous hyphae and small pellets and yielded high mycelia biomass and polysaccharide production [16].

Recently, morphology engineering strategies including targeted metabolic engineering, osmolality or operational parameter optimization have been proposed to control filamentous shape and bioprocess performance [12, 17]. Microparticle-enhanced cultivation (MPEC) such as Talc (magnesium silicate), aluminum oxide and titanium oxide was regarded as one of morphology engineering strategies to control fungal morphology development to improve productivity by preventing bulk fungal growth and providing homogenized fermentation broth [18]. For example, addition of aluminum oxide and hydrous magnesium silicate caused a dispersion of Caldariomyces fumago cells up to a level of single hyphae and a fivefold enhanced chloroperoxidase (CPO) production [19]. Additionally, silicate precisely adjusted the morphology of $A$. niger to a number of different distinct morphological forms [20] and Talc also led to a $50.30 \%$ increase of 3-poly-L-lysine production in Streptomyces sp. M-Z18 fed-batch fermentation [14].

Grifola frondosa is a well-known edible mushroom belonging to the order Aphyllopherales and family Polyporeceae. G. frondosa polysaccharides have recently attracted considerable attention for its physiological activities such as anti-tumor, hypoglycemic and immunostimulating properties [4, 21-23]. Our previous studies have well investigated the fermentation process optimization to maximally produce G. frondosa mycelia and mycelial/exo-polysaccharide, and elucidated the structure of mycelial polysaccharide and its antitumor mechanism [16, 21, 24]. However, relationships between fermentation conditions, mycelial growth, and polysaccharide biosynthesis need still to be further elucidated. Currently no references of microparticle-enhanced morphology engineering strategies are available to control fungal morphology and improve mycelial growth and polysaccharide biosynthesis of G. frondosa. Therefore, based on our previous results, the present study aimed to investigate effect of microparticle Talc addition on the mycelial growth and polysaccharide production of G. frondosa, and find a clue of the relationship between polysaccharide biosynthesis and morphological changes.

\section{Methods}

\section{Microorganism and medium}

Grifola frondosa GF 9801 was obtained and kept in our laboratory [24]. The strain was maintained on potato dextrose agar (PDA) after incubation at $28^{\circ} \mathrm{C}$ for 7 days, stored at $4{ }^{\circ} \mathrm{C}$ and subsequently subcultured every 2 months. The seed culture was grown in a $250 \mathrm{~mL}$ Erlenmeyer flask containing $75 \mathrm{~mL}$ of the medium (glucose $20 \mathrm{~g} / \mathrm{L}$, peptone $5 \mathrm{~g} / \mathrm{L}, \mathrm{KH}_{2} \mathrm{PO}_{4} 1.5 \mathrm{~g} / \mathrm{L}$, and $\mathrm{MgSO}_{4} \cdot 7 \mathrm{H}_{2} \mathrm{O} 0.75 \mathrm{~g} / \mathrm{L}$ ) at $28{ }^{\circ} \mathrm{C}$ in a shake incubator at $150 \mathrm{rpm}$ for 6 days. Media for 500-mL flask fermentation with $150 \mathrm{~mL}$ of working volume contained glucose $60 \mathrm{~g} / \mathrm{L}$, peptone $6 \mathrm{~g} / \mathrm{L}, \mathrm{KH}_{2} \mathrm{PO}_{4} 3 \mathrm{~g} / \mathrm{L}$ and $\mathrm{MgSO}_{4} \cdot 7 \mathrm{H}_{2} \mathrm{O}$ $1.5 \mathrm{~g} / \mathrm{L}$.

\section{Inoculum preparation and shake-flask fermentation}

Grifola frondosa was initially cultivated on PDA at $28{ }^{\circ} \mathrm{C}$ for 7 days. 10 pieces (approximately $5 \times 5 \mathrm{~mm}$ ) of the culture was transferred to the seed medium with a sterilized self-designed cutter.

To investigate the effect of Talc $\left(3 \mathrm{MgO} \cdot 4 \mathrm{SiO}_{2} \cdot \mathrm{H}_{2} \mathrm{O}\right.$, $45 \mu \mathrm{m}$ ) on the fermentation performance of $\mathrm{G}$. frondosa, Talc with the concentrations of $0,0.1,0.5,1.0,3.0,6.0$, $10.0,15.0$, and $20.0 \mathrm{~g} / \mathrm{L}$ was added in the $150 \mathrm{~mL}$ fermentation media in the 500-mL shake flasks after inoculating with $10 \%(\mathrm{v} / \mathrm{v})$ of the seed. The fermentation tests were conducted at $28{ }^{\circ} \mathrm{C}$ with shaking at $150 \mathrm{rpm}$ for 6 days. After removing Talc with 300 micron-size nylon mesh, the samples were collected from each flask for analyzing mycelial morphology, mycelial biomass and exopolysaccharide concentrations, and polysaccharides compositions and enzymes activities related to polysaccharide-synthesis in G. frondosa.

\section{Morphological characterization}

The microscopic analyses of G. frondosa mycelia were conducted by adding $3 \mathrm{~mL}$ of the culture broth into a Petri containing $10 \mathrm{~mL}$ of distilled water and capturing the images with a digital camera (Olympus Optical Co., Ltd., Tokyo, Japan) mounted on the stereomicroscope (Olympus Optical Co., Ltd., Tokyo, Japan). Morphological measurements were carried out using the Image-Pro Plus 6.0 software (Media Cybernetics Inc., MD, USA). The morphologies of 20 pellets in each sample were characterized by measuring the area, perimeter, equivalent diameter, circularity, and roughness [25]. Equivalent diameter is the diameter of a circle having the same area with the measured feature. It is derived from area (A) as $\mathrm{D}=\sqrt{4 \mathrm{~A} / \pi}$. According to the equivalent diameter, the mycelial pellet were divided into L-fraction (diameter $\geq 1.5 \mathrm{~cm}$ ), M-fraction (diameter between 0.5 with $1.5 \mathrm{~cm}$ ) and S-fraction (diameter $<0.5 \mathrm{~cm}$ ). The circularity was estimated as the ratio of the Feret's minimum diameter to the Feret's maximum diameter of the pellets or aggregates. Roughness (R) was measured using the following equation: $R=$ (pellet aggregate perimeter) ${ }^{2} /$ $(4 \pi \times$ pellet area $)$. 


\section{Fermentation performance}

Fermentation performance of G. frondosa was evaluated based on concentrations of mycelia biomass and exo-polysaccharide. Grifola frondosa mycelia concentration was measured by centrifuging the collected broth at $10,000 \times g$ for $10 \mathrm{~min}$ and freeze-drying the precipitated mycelia after three-time distilled water wash. Exo-polysaccharide concentration was weighted by mixing the resulting broth vigorously with four times volume of ethanol $(100 \%, \mathrm{v} / \mathrm{v})$, centrifuging to obtain the precipitate at $12,000 \times g$ for $20 \mathrm{~min}$ and freeze-drying.

Mycelial polysaccharide was obtained by collecting the cultured mycelia by centrifugation at $10,000 \times g$ for $10 \mathrm{~min}$, extracting the mycelia at $90^{\circ} \mathrm{C}$ for $2 \mathrm{~h}$, precipitating the extracts with four times volume of ethanol (100\%, $\mathrm{v} / \mathrm{v}$ ) for $24 \mathrm{~h}$ at $4{ }^{\circ} \mathrm{C}$, freeze-drying and weighting the precipitates. The mycelial polysaccharide yield was calculated by dividing the mycelial polysaccharide ( $g$ ) by the freeze-dried mycelial biomass (g).

\section{Monosaccharide composition analysis of mycelial polysaccharide and exo-polysaccharide}

Monosaccharide compositions and their ratios in mycelial polysaccharide and exo-polysaccharide were determined by absolute hydrolysis [26]. Briefly, Mycelial polysaccharide and exo-polysaccharide were hydrolyzed with $0.3 \mathrm{~mL} 72 \%(\mathrm{w} / \mathrm{v})$ sulphuric acid for $30 \mathrm{~min}$ at $30{ }^{\circ} \mathrm{C}$, followed with addition of $8.4 \mathrm{~mL}$ of distilled water and incubation at $121{ }^{\circ} \mathrm{C}$ for $1 \mathrm{~h}$. The hydrolysate was neutralized with $\mathrm{CaCO}_{3}$, evaporated to dryness, and acetylated with $\mathrm{Ac}_{2} \mathrm{O}$-Pyridine at $90{ }^{\circ} \mathrm{C}$ for $30 \mathrm{~min}$. Inositol was used as an internal standard. The resulting alditol acetate was analyzed by gas chromatography using an Agilent Technologies 7890A Network gas chromatography using HP-5MS capillary column $(30 \mathrm{~m} \times 0.25 \mathrm{~mm}$ i.d.) (Hewlett-Packard, Avondale, PA, USA) with nitrogen as carrier gas. The analysis was carried out with the temperature from 130 to $240{ }^{\circ} \mathrm{C}$ at $4{ }^{\circ} \mathrm{C} / \mathrm{min}$ and maintaining the temperature for $5 \mathrm{~min}$. Samples $(1 \mu \mathrm{L})$ were injected in the split mode at the ratio of 40:1. The products were identified by typical retention times of corresponding standards.

\section{Determination of PGI, UGP, UGDG, GMPPB and UGE activities associated with polysaccharide-synthesis} Grifola frondosa mycelia were harvested by centrifugation at $10,000 \times g, 4{ }^{\circ} \mathrm{C}$ for $10 \mathrm{~min}$ after 6 -day fermentation, washed twice with $20 \mathrm{mM}$ phosphate buffer $(\mathrm{pH}$ $6.5)$ to remove the residual media and talcum. The mycelia were ground after mixing with $20 \mathrm{mM}$ phosphate buffer, and centrifuged at $10,000 \times g, 4{ }^{\circ} \mathrm{C}$ for $10 \mathrm{~min}$ to collect the supernatant to determine activities of the polysaccharide-synthesis related enzymes.
Polysaccharide-synthesis related enzymes including PGI (Phosphoglucose isomerase), UGP (UDP-glucose pyrophosphorylase), UGDG (UDP-glucose dehydrogenase), GMPPB (GDP-mannose pyrophosphorylase) and UGE (UDP-glucose-4-epimerase) were determined according to the previously reported method [27, 28] with slight modification. All in vitro enzyme assays were performed at $30{ }^{\circ} \mathrm{C}$ in a volume of $250 \mu \mathrm{L}$ with $220 \mu \mathrm{L}$ of reagents listed in Table 1 , and $30 \mu \mathrm{L}$ of cell extract. Formation or disappearance of $\mathrm{NAD}(\mathrm{P}) \mathrm{H}$ was monitored by spectrophotometrically measuring the absorbance at $340 \mathrm{~nm}(\varepsilon 340=6.22 / \mathrm{M} / \mathrm{cm})$. The activities of the enzymes described below were expressed in nmol $\mathrm{NAD}(\mathrm{P}) \mathrm{H} /(\mathrm{mg}$ protein $) / \mathrm{min}$. The protein content of the extracts was determined using the Bradford method [29] and was compared with a bovine serum albumin standard. The blank for each enzyme was the same reaction condition with cell extract after incubation at $80{ }^{\circ} \mathrm{C}$ for $20 \mathrm{~min}$.

\section{Statistical analysis}

All experiments were performed in triplicates. The data were expressed as means \pm standard deviations $(n=3)$. Data sets were evaluated by one-way analysis of variance (ANOVA). Statistical comparisons were made on the basis of the $p$ value $(\alpha=0.05)$ followed by Duncan's new multiple range test.

\section{Results and discussion}

\section{Effect of Talc concentration on the morphology of Grifola frondosa}

Morphological forms of fungi and mushrooms vary from dispersed mycelial filaments to dense pellets which affect the amounts of secondary metabolites [30]. Our previous results also proved that $G$. frondosa mycelia had at least three typical morphological appearances including pellets with a rigid pellet core and hairy region, clumps with low roughness and filaments with uncertain shape and small size [16]. Figure 1 gave the influence of added Talc (average diameter of $45 \mu \mathrm{m}$ ) concentration on G. frondosa morphology during 6-day fermentation. G. frondosa mycelia had the bulky appearance of pellets with radial fluffs when the added Talc concentrations were $0.1-$ $1.0 \mathrm{~g} / \mathrm{L}$. Increase of Talc concentration to $6.0-15.0 \mathrm{~g} / \mathrm{L}$ decreased the rigidity and radial fluffs of mycelia and led to spherical and smooth pellets, even looser hyphal fragments. Mycelia of $G$. frondosa had the smallest size and free hypha at the Talc concentration of $20.0 \mathrm{~g} / \mathrm{L}$.

Changes of mycelial size and its distribution during submerged culture by G. frondosa under different Talc concentrations were shown in Fig. 2. Majority of G. frondosa mycelia without Talc addition belonged to L (diameter of mycelia pellet $\geq 1.5 \mathrm{~cm}$ ) or $\mathrm{M}$-fraction (diameter of 
Table 1 Reaction mixtures for determining the enzymes activities related to polysaccharide synthesis of Grifola frondosa

\begin{tabular}{|c|c|c|c|}
\hline Enzymes & Reagents & Reagent concentration (mM) & Volume $(\mu \mathrm{L})$ \\
\hline \multirow[t]{7}{*}{ UDP-glucose pyrophosphorylase (UGP) } & Tris- $\mathrm{HCl}(\mathrm{pH} 7.8)$ & 50.0 & 200.0 \\
\hline & Sodium pyrophosphate & 4.0 & 5.0 \\
\hline & UDP-GIC & 0.4 & 5.0 \\
\hline & $\mathrm{MgCl}_{2}$ & 14.0 & 5.0 \\
\hline & $\mathrm{NADP}^{+}$ & 0.4 & 2.0 \\
\hline & PGM & $2.1 \mathrm{U}$ & 1.1 \\
\hline & G-6-PD & $4.0 \mathrm{U}$ & 1.9 \\
\hline \multirow[t]{5}{*}{ UDP-glucose dehydrogenase (UGDG) } & Tris- $\mathrm{HCl}(\mathrm{pH} 7.5)$ & 100.0 & 200.0 \\
\hline & UDP-GlC & 5.0 & 5.0 \\
\hline & $\mathrm{MgCl}_{2}$ & 1.0 & 5.0 \\
\hline & $\mathrm{NADP}^{+}$ & 1.0 & 5.0 \\
\hline & DTT & 1.0 & 5.0 \\
\hline \multirow[t]{10}{*}{ GDP-mannose pyrophosphorylase (GMPPB) } & MOPS (pH 7.0) & 100.0 & 187.5 \\
\hline & D-GlC & 4.0 & 3.2 \\
\hline & Sodium pyrophosphate & 1.0 & 1.25 \\
\hline & $\mathrm{NADP}^{+}$ & 1.0 & 5.0 \\
\hline & $\mathrm{MgCl}_{2}$ & 10.0 & 3.6 \\
\hline & GDP-Man & 1.0 & 4.1 \\
\hline & ADP & 1.0 & 3.0 \\
\hline & NDPK & $5.0 \mathrm{U}$ & 5.0 \\
\hline & $\mathrm{HK}$ & $5.0 \mathrm{U}$ & 5.0 \\
\hline & G-6-PD & $5.0 \mathrm{U}$ & 2.35 \\
\hline \multirow[t]{5}{*}{ UDP-glucose-4-epimerase (UGE) } & Tris- $\mathrm{HCl}(\mathrm{pH} 8.5)$ & 50.0 & 171.4 \\
\hline & UDP-Gal & 0.2 & 2.5 \\
\hline & $\mathrm{MgCl}_{2}$ & 5.0 & 6.1 \\
\hline & $\mathrm{NAD}^{+}$ & 0.5 & 2.5 \\
\hline & UGDG & $0.015 \mathrm{U}$ & 37.5 \\
\hline
\end{tabular}

mycelia pellet ranging from 0.5 to $1.5 \mathrm{~cm}$ ) with the ratios of 45.2 and $49.7 \%$, respectively. The increase of Talc concentration to $20.0 \mathrm{~g} / \mathrm{L}$ resulted in the significant decrease of $\mathrm{L}$ fraction ratio to approximately $4.12 \%$. M-fraction ratio reached to maximum level of $58.12 \%$ when added Talc concentration of $3.0 \mathrm{~g} / \mathrm{L}$, and then gradually decreased to $20.65 \%$ with the increased Talc concentration to $20.0 \mathrm{~g} / \mathrm{L}$. Accordingly, the S-fraction (diameter of mycelia pellet $<0.5 \mathrm{~cm}$ ) became to the majority with the maximum level of $75.41 \%$ at Talc concentration of $20.0 \mathrm{~g} / \mathrm{L}$. The present study indicated that addition of Talc also could decrease the diameters of G. frondosa mycelia for controlling homogeneous pellet size, which possibly due to the collision between Talc with mycelia, the shear stress exerted by the Talc and the dissociation of mycelium gathering [19]. Similar results could be found in the decrease of Streptomyces sp. mycelial diameter from 297.63 to $205.65 \mu \mathrm{m}$ with supplementation of $10.0 \mathrm{~g} / \mathrm{L}$ Talc [14].

Table 2 summarized the morphological parameters of G. frondosa S-fraction mycelia with Talc concentrations up to $20.0 \mathrm{~g} / \mathrm{L}$ after 6-day fermentation. Addition of Talc with concentration of $20.0 \mathrm{~g} / \mathrm{L}$ resulted in the minimum area, perimeter and equivalent diameter of $0.49 \mathrm{~mm}^{2}$, 4.11 and $0.79 \mathrm{~mm}$, respectively, which also proved that the high Talc concentration were negative to the pellet formation. Our previous results showed that supplementation of $20.0 \mathrm{~g} / \mathrm{L}$ microparticle $\mathrm{Al}_{2} \mathrm{O}_{3}$ decreased the area, perimeter and equivalent diameter of $G$. frondosa mycelia to $1.07 \mathrm{~mm}^{2}, 6.65$ and $1.17 \mathrm{~mm}$ [31]. Talc concentration of $3.0 \mathrm{~g} / \mathrm{L}$ gave the maximum roughness of 4.86 . From Table 2, Talc concentration of $0.1-15.0 \mathrm{~g} / \mathrm{L}$ had a slight influence on the circularity from 0.73 to $0.81(p>0.05)$.

\section{Effect of Talc concentration on fermentation performance of Grifola frondosa}

Figure 3 showed the influence of Talc concentration on the fermentation performance of $G$. frondosa. Mycelia growth of $G$. frondosa showed an increasing trend with the increase of Talc concentrations from 0.1 to $6.0 \mathrm{~g} / \mathrm{L}$. Talc concentration of $6.0 \mathrm{~g} / \mathrm{L}$ gave the maximum mycelia biomass of to $19.25 \mathrm{~g} / \mathrm{L}$ with $55.0 \%$ increase to that of 


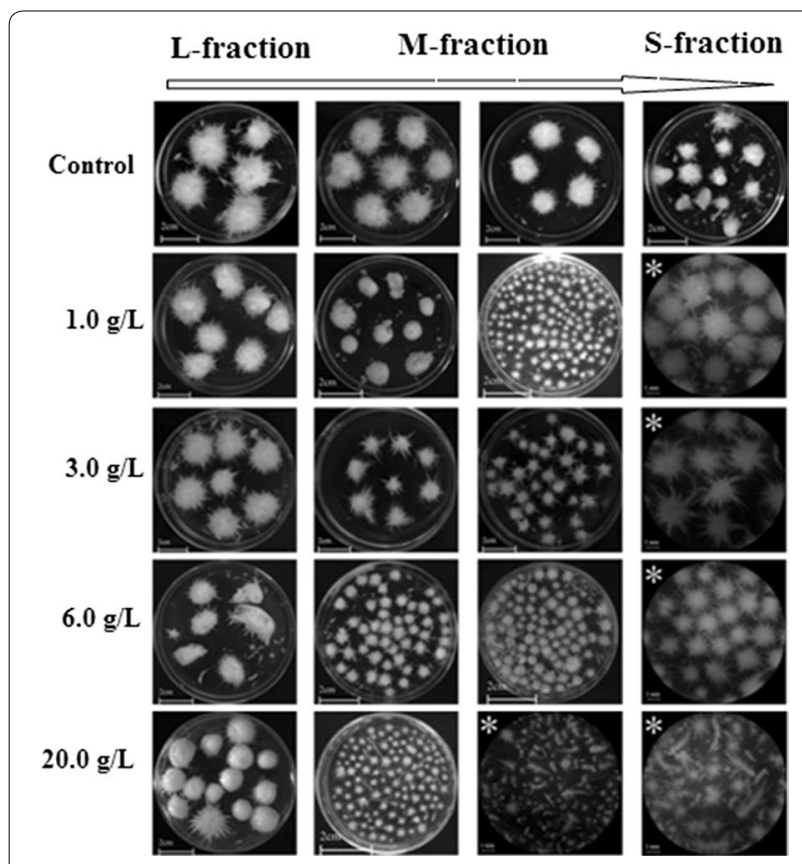

Fig. 1 Typical morphological changes of G. frondosa GF9801 at different Talc concentrations ranging from 0.1 to $20.0 \mathrm{~g} / \mathrm{L}$ during the 6-day fermentation period at $28^{\circ} \mathrm{C}$. (Figures having asterisk with the bar of $1 \mathrm{~mm}$, and others having no asterisk with the bar of $2 \mathrm{~cm}$ )

control. Too high concentration of Talc had the negative influence on the mycelial biomass with the minimum biomass concentration of $13.20 \mathrm{~g} / \mathrm{L}$ when Talc concentration increased to $20 \mathrm{~g} / \mathrm{L}$. This finding contradicted the cultivations of Aspergillus terreus ATCC 20542 with highest biomass concentration at 10-15 g/L Talc [32] and Streptomyces sp. M-Z18 with maximum DCW of $7.05 \mathrm{~g} / \mathrm{L}$ in shake-flask fermentation at $20 \mathrm{~g} \mathrm{~L} / \mathrm{L}$ of Talc addition [14].

Exo-polysaccharide production increased to the maximum level of $3.12 \mathrm{~g} / \mathrm{L}$ when the added Talc concentration increased to $6.0 \mathrm{~g} / \mathrm{L}$, and then decreased to $1.48 \mathrm{~g} / \mathrm{L}$ at the Talc concentration of $20 \mathrm{~g} / \mathrm{L}$. Mycelia polysaccharide showed the highest yield of $0.24 \mathrm{~g} / \mathrm{g}$ at Talc concentration of $3.0 \mathrm{~g} / \mathrm{L}$, and lowest yield of $0.05 \mathrm{~g} / \mathrm{g}$ with addition of $20.0 \mathrm{~g} / \mathrm{L}$ of Talc, which might contribute to the higher ratios of $\mathrm{M}$ - and S-mycelial fractions benefiting the heat and mass transfer. Similarly, Driouch et al. found that $10 \mathrm{~g} / \mathrm{L}$ of Talc increased the 4 times of glucoamylase (GA) activity [33], and Ren et al. also found that Talc with concentration of over $10 \mathrm{~g} / \mathrm{L}$ would lower the target $\varepsilon$-poly-Llysine production [14]. Hence, it could be concluded that addition of 3.0-6.0 g/L of Talc would be beneficial for exo-polysaccharide and mycelia polysaccharide production of G. frondosa.

\section{Effect of Talc addition on monosaccharide compositions/ percentages and polysaccharide synthesis related enzymes of Grifola frondosa}

Tables 3 and 4 presented the changes of monosaccharide compositions and their ratios in the exo-polysaccharide and mycelial polysaccharides of $G$. frondosa without or with Talc. Similar to our previous obtained results,

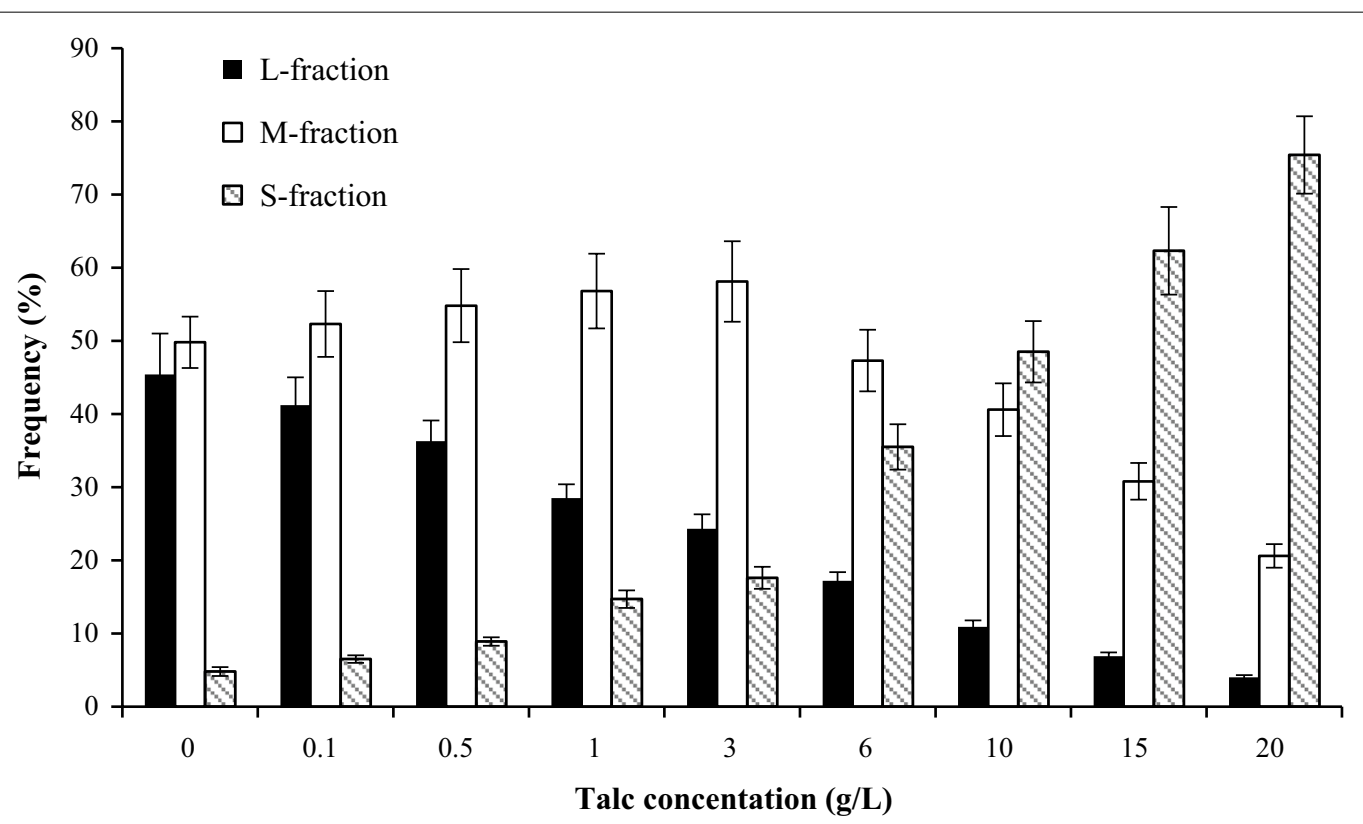

Fig. 2 Changes of mycelial forms during submerged culture by $\mathrm{G}$. frondosa under different Talc concentrations ranging from $0.1 \mathrm{~g} / \mathrm{L}$ to $20.0 \mathrm{~g} / \mathrm{L}$ during the 6 -day fermentation period at $28^{\circ} \mathrm{C}$. (Frequency $(\%)=$ mycelia pellet No. of fraction/ total mycelia pellets $\times 100 \%$; L-fraction: diameter of mycelia pellet $\geq 1.5 \mathrm{~cm}, \mathrm{M}$-fraction: diameter of mycelia pellet ranging from $0.5 \mathrm{~cm}$ to $1.5 \mathrm{~cm}$, S-fraction: diameter of mycelia pellet <0.5 cm) 
Table 2 Morphological parameters of pellets/mycelial aggregates during submerged culture by G. frondosa under different Talc concentrations

\begin{tabular}{llllll}
\hline Talc concentration $(\mathbf{g} / \mathbf{L})$ & Area $\left(\mathbf{m m}^{\mathbf{2}}\right)$ & Perimeter $(\mathbf{m m})$ & Equivalent diameter $(\mathbf{m m})$ & Roughness & Circularity \\
\hline 0 & $6.75 \pm 0.76 \mathrm{a}$ & $20.25 \pm 1.34 \mathrm{a}$ & $2.93 \pm 0.19 \mathrm{a}$ & $4.83 \pm 0.50 \mathrm{a}$ & $0.73 \pm 0.03 \mathrm{a}$ \\
0.1 & $6.23 \pm 0.54 \mathrm{ab}$ & $17.56 \pm 1.43 \mathrm{~b}$ & $2.82 \pm 0.24 \mathrm{ab}$ & $3.94 \pm 0.24 \mathrm{~b}$ & $0.74 \pm 0.02 \mathrm{a}$ \\
0.5 & $5.65 \pm 0.34 \mathrm{~b}$ & $14.80 \pm 1.26 \mathrm{c}$ & $2.68 \pm 0.21 \mathrm{ab}$ & $3.08 \pm 0.30 \mathrm{~cd}$ & $0.81 \pm 0.04 \mathrm{a}$ \\
1.0 & $4.75 \pm 0.51 \mathrm{c}$ & $14.65 \pm 1.57 \mathrm{c}$ & $2.46 \pm 0.32 \mathrm{~b}$ & $3.60 \pm 0.14 \mathrm{bc}$ & $0.80 \pm 0.07 \mathrm{a}$ \\
3.0 & $3.11 \pm 0.23 \mathrm{~d}$ & $13.78 \pm 1.24 \mathrm{~cd}$ & $1.99 \pm 0.15 \mathrm{c}$ & $4.86 \pm 0.49 \mathrm{a}$ & $0.74 \pm 0.05 \mathrm{a}$ \\
6.0 & $3.10 \pm 0.31 \mathrm{~d}$ & $11.93 \pm 1.09 \mathrm{~d}$ & $1.99 \pm 0.24 \mathrm{c}$ & $3.66 \pm 0.33 \mathrm{bc}$ & $0.76 \pm 0.03 \mathrm{a}$ \\
10.0 & $1.94 \pm 0.18 \mathrm{e}$ & $8.69 \pm 0.75 \mathrm{e}$ & $1.57 \pm 0.07 \mathrm{~d}$ & $3.09 \pm 0.28 \mathrm{~cd}$ & $0.79 \pm 0.04 \mathrm{a}$ \\
15.0 & $1.62 \pm 0.26 \mathrm{e}$ & $8.33 \pm 0.45 \mathrm{e}$ & $1.44 \pm 0.25 \mathrm{~d}$ & $3.40 \pm 0.21 \mathrm{bc}$ & $0.79 \pm 0.08 \mathrm{a}$ \\
20.0 & $0.49 \pm 0.05 f$ & $4.11 \pm 0.38 \mathrm{f}$ & $0.79 \pm 0.03 \mathrm{e}$ & $2.73 \pm 0.18 \mathrm{~d}$ & $0.53 \pm 0.01 \mathrm{~b}$ \\
\hline
\end{tabular}

Each data point was the mean of three replicate samples

Roughness means the irregularity of the perimeter of pellet; Circularity represents the similarity with a circle changing from 0 to $1 ; a, b, c, d, e$ and $f$ represent the significant difference for $p<0.05$

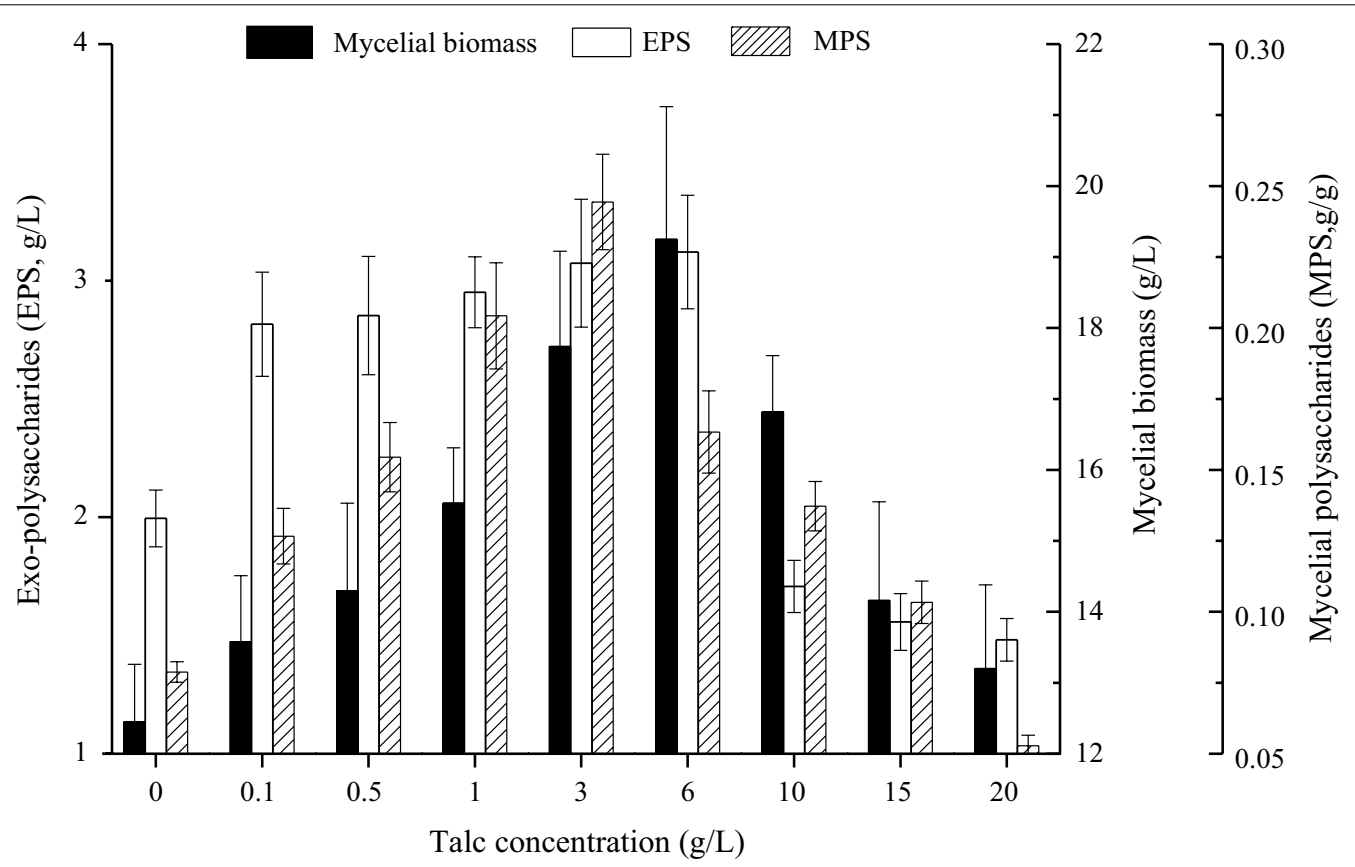

Fig. 3 Changes of mycelial biomass, exo-polysaccharides (EPS) and mycelial polysaccharides (MPS) production during submerged culture by G. frondosa under different Talc concentrations ranging from 0.1 to $20.0 \mathrm{~g} / \mathrm{L}$ during the 6 -day fermentation period at $28^{\circ} \mathrm{C}$

exo-polysaccharides in the control samples were mainly composed of glucose $(98.25 \%)$ with minor amounts of mannose $(0.89 \%)$ and arabinose $(0.86 \%)$ (Table 3$)$. Presence of Talc possibly shifted sugar compositions in the exo-polysaccharide of $G$. frondosa. After adding Talc microparticles with the increasing concentrations to $6.0 \mathrm{~g} / \mathrm{L}$, percentages of glucose decreased to the lowest level of $77.96 \%$ while arabinose percentage increased ranging from 2.79 to $5.43 \%$. Interestingly, galactose appeared and reached to the highest percentage of $16.77 \%$ with adding $6.0 \mathrm{~g} / \mathrm{L}$ of Talc.
From Table 4, Talc also significantly altered the monosaccharide compositions in mycelial polysaccharide by decreasing glucose percentage to $15.22 \%(6.0 \mathrm{~g} / \mathrm{L}$ of Talc), and increasing galactose percentage to $31.9 \%(20.0 \mathrm{~g} / \mathrm{L}$ of Talc) and mannose percentage to $62.76 \%(6.0 \mathrm{~g} / \mathrm{L}$ of Talc), respectively. The previous data also proved that the aeration rate of $0.50 \mathrm{vvm}$ caused the sugar metabolic shift with the lowest arabinose percentage of $2.83 \%$ and highest mannose percentage of $35.73 \%$ [16]. Similar conclusion also has been obtained that the varied dissolved 
Table 3 Effects of Talc concentration on monosaccharide composition of exo-polysaccharide isolated from $G$. frondosa GF9801

\begin{tabular}{lllll}
\hline $\begin{array}{l}\text { Talc } \\
\text { concen- } \\
\text { tration } \\
(\mathbf{g} / \mathbf{L})\end{array}$ & \multicolumn{4}{l}{ Monosaccharide compositions (\%) } \\
\cline { 2 - 5 } & Arabinose & Mannose & Glucose & Galactose \\
\hline 0 & $0.86 \pm 0.01 \mathrm{f}$ & $0.89 \pm 0.04 \mathrm{c}$ & $98.25 \pm 4.12 \mathrm{a}$ & - \\
0.1 & $5.43 \pm 0.36 \mathrm{a}$ & - & $94.57 \pm 5.62 \mathrm{a}$ & - \\
0.5 & $2.83 \pm 0.15 \mathrm{de}$ & - & $93.47 \pm 4.29 \mathrm{a}$ & $3.70 \pm 0.17 \mathrm{~cd}$ \\
1.0 & $3.31 \pm 0.17 \mathrm{c}$ & - & $92.51 \pm 6.13 \mathrm{a}$ & $4.18 \pm 0.32 \mathrm{c}$ \\
3.0 & $2.79 \pm 0.11 \mathrm{de}$ & $3.04 \pm 0.20 \mathrm{a}$ & $90.95 \pm 4.81 \mathrm{a}$ & $3.22 \pm 0.16 \mathrm{~d}$ \\
6.0 & $3.22 \pm 0.34 \mathrm{c}$ & $2.05 \pm 0.21 \mathrm{~b}$ & $77.96 \pm 3.54 \mathrm{~b}$ & $16.77 \pm 1.32 \mathrm{a}$ \\
10.0 & $3.00 \pm 0.22 \mathrm{~cd}$ & $0.94 \pm 0.02 \mathrm{c}$ & $90.45 \pm 8.15 \mathrm{a}$ & $5.61 \pm 0.37 \mathrm{~b}$ \\
15.0 & $3.85 \pm 0.17 \mathrm{~b}$ & $0.91 \pm 0.04 \mathrm{c}$ & $90.73 \pm 6.41 \mathrm{a}$ & $4.51 \pm 0.27 \mathrm{c}$ \\
20.0 & $2.58 \pm 0.14 \mathrm{e}$ & $0.59 \pm 0.03 \mathrm{~d}$ & $96.10 \pm 4.82 \mathrm{a}$ & $0.73 \pm 0.04 \mathrm{e}$ \\
\hline
\end{tabular}

Each data point was the mean of three replicate samples

$a, b, c, d$, e and f represent the significant difference for $p<0.05$

oxygen concentration resulted in the metabolic shifts in Yarrowia lipolytica by affecting the morphological characteristics and enzymes activity such as ATP-citrate lyase in lipid biosynthesis [34].

Compared to the bacterial polysaccharides [35, 36], the knowledge about pathways and molecular mechanisms of fungal polysaccharide synthesis is still limited. Some pathways of fungal polysaccharides biosynthesis are proposed based on the monosaccharide compositions and activities polysaccharide-synthesis associated enzymes using the synthesis pathways of bacterial polysaccharide as a Ref. [27]. Based on the changes of monosaccharide compositions/percentages in exo-polysaccharide and mycelial polysaccharide of G. frondosa, the activities of five key enzymes including UGDG, PGI, UGP, GMPPB and UGE possibly involved in the polysaccharides biosynthesis were determined after 6-day fermentation and shown in Table 5. UGP and UGDG play the key roles on UDP-glucose and UDParabinose synthesis [37, 38]. From Table 5, UGP had the lowest activity of $91.0 \mathrm{mU} / \mathrm{mg}$ while UGDG showed the highest activity of $81.0 \mathrm{mU} / \mathrm{mg}$ with Talc concentration of $6.0 \mathrm{~g} / \mathrm{L}$, which were in accordance with the trends of glucose and arabinose percentages. GMPPB is the sole enzymes to produce GDP-mannose [39]. With the increased concentration of Talc to $6.0 \mathrm{~g} / \mathrm{L}$, GMPPB activity increased to the maximum level of $93.0 \mathrm{mU} / \mathrm{mg}$ with the corresponding mannose percentage of $62.76 \%$ in mycelial polysaccharide and $2.05 \%$ in exo-polysaccharide. UGE catalyzes the interconversion between UDPglucose and UDP-galactose [40]. From Table 5, UGE activity showed the significant changes to $165 \mathrm{mU} / \mathrm{mg}$ with the increase of galactose percentage to $31.19 \%$ in mycelial polysaccharide.

From the above results, the possible polysaccharide synthesis pathway in $G$. frondosa could be proposed as follows. Exo-polysaccharide of G. frondosa was synthesized by converting glucose to UDP-glucose with UGP and polymerizing UDP-glucose to glucan with glucan synthases, and finally secreted to the broth. Simultaneously, glucose in G. frondosa cells was fermented to UDP-glucose, UDP-galactose and GDP-mannose using PGI, UGE, UGDG and GMPPB which were assembled to mycelial polysaccharides. Addition of Talc affected morphological appearance of $G$. frondosa by changing shear stress and accelerated the collision between talc with mycelia, which increased contact area with the dissolved oxygen and nutrients, altered the expression of polysaccharide synthesis related enzymes and finally changed the monosaccharide compositions in mycelial polysaccharides and exo-polysaccharide.

Table 4 Effect of Talc concentrations on monosaccharide composition of mycelial polysaccharide produced by G. frondosa GF9801

\begin{tabular}{llllr}
\hline Talc concentration $(\mathbf{g} / \mathbf{L})$ & \multicolumn{3}{l}{ Monosaccharide compositions (\%) } \\
\cline { 2 - 5 } & Arabinose & Mannose & Glucose & Galactose \\
\hline 0 & $3.75 \pm 0.14 \mathrm{bc}$ & $43.03 \pm 1.23 \mathrm{bcd}$ & $50.26 \pm 2.57 \mathrm{~b}$ & $2.96 \pm 0.17 \mathrm{ef}$ \\
0.1 & $2.23 \pm 0.22 \mathrm{e}$ & $32.82 \pm 1.26 \mathrm{f}$ & $60.15 \pm 4.24 \mathrm{a}$ & $4.80 \pm 0.27 \mathrm{e}$ \\
0.5 & $2.19 \pm 0.14 \mathrm{e}$ & $34.36 \pm 1.56 \mathrm{f}$ & $62.20 \pm 4.47 \mathrm{a}$ & $1.25 \pm 0.11 \mathrm{f}$ \\
1.0 & $4.11 \pm 0.31 \mathrm{~b}$ & $42.06 \pm 2.76 \mathrm{bcd}$ & $49.61 \pm 3.25 \mathrm{~b}$ & $4.22 \pm 0.23 \mathrm{e}$ \\
3.0 & $1.81 \pm 0.09 \mathrm{e}$ & $43.85 \pm 2.54 \mathrm{bc}$ & $43.38 \pm 4.25 \mathrm{c}$ & $10.96 \pm 0.86 \mathrm{e}$ \\
6.0 & $6.71 \pm 0.36 \mathrm{a}$ & $62.76 \pm 3.87 \mathrm{a}$ & $15.22 \pm 0.67 \mathrm{e}$ & $15.31 \pm 0.92 \mathrm{c}$ \\
10.0 & $3.56 \pm 0.32 \mathrm{c}$ & $40.18 \pm 3.45 \mathrm{~cd}$ & $44.05 \pm 2.73 \mathrm{c}$ & $12.21 \pm 0.38 \mathrm{~d}$ \\
15.0 & $3.95 \pm 0.28 \mathrm{bc}$ & $46.40 \pm 3.51 \mathrm{~b}$ & $29.57 \pm 1.48 \mathrm{~d}$ & $20.08 \pm 1.45 \mathrm{~b}$ \\
20.0 & $2.76 \pm 0.25 \mathrm{~d}$ & $38.10 \pm 2.71 \mathrm{de}$ & $27.95 \pm 2.57 \mathrm{~d}$ & $31.19 \pm 2.48 \mathrm{a}$
\end{tabular}

Each data point was the mean of three replicate samples

$a, b, c, d, e$ and $f$ represent the significant difference for $p<0.05$ 


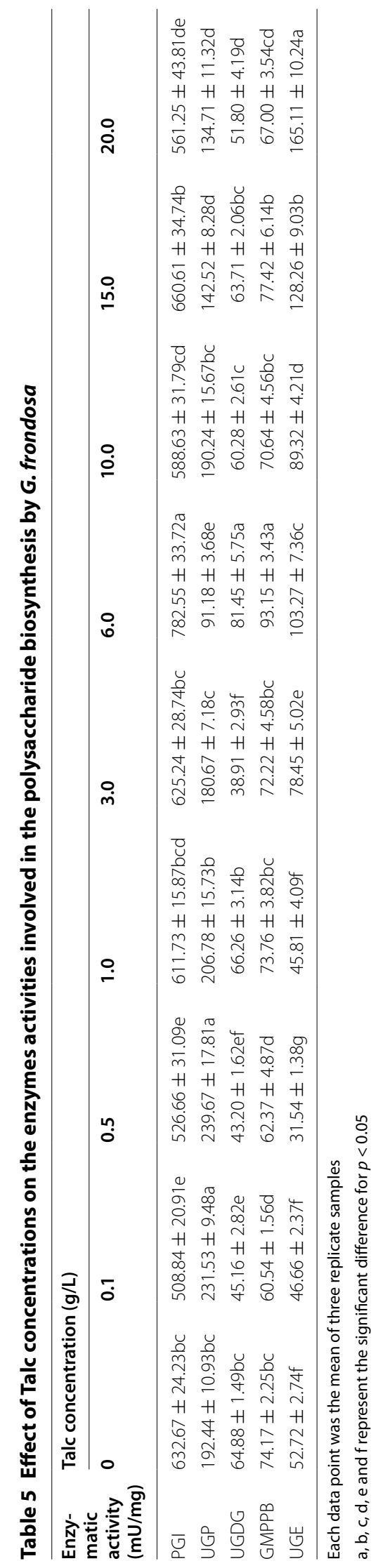




\section{Conclusion}

In order to improve mycelial growth and polysaccharide production by $G$. frondosa, selection of microparticle Talc concentration was of highest importance. Adding Talc $(45 \mu \mathrm{m})$ with the concentration of $3.0-6.0 \mathrm{~g} / \mathrm{L}$ decreased the diameter of the pellets and increased the percentage of S-fraction mycelia of G. frondosa. Talc gave the maximum mycelial biomass of $19.25 \mathrm{~g} / \mathrm{L}$ and exopolysaccharide of $3.12 \mathrm{~g} / \mathrm{L}$ at $6.0 \mathrm{~g} / \mathrm{L}$ of Talc and mycelial polysaccharide of $0.24 \mathrm{~g} / \mathrm{g}$ at $3.0 \mathrm{~g} / \mathrm{L}$ of Talc. The presence of Talc significantly affected the monosaccharide compositions and percentages in mycelial and exopolysaccharides, and enzymes activities associated with polysaccharide synthesis. The results suggested that addition of Talc would change the fermentation performance by affecting morphological appearance and polysaccharide-biosynthesis related enzymes activities of G. frondosa. Further investigations to construct the G. frondosa mutants by over-expressing and/or gene-silencing the genes involved mycelial and exo-polysaccharide synthesis are ongoing in our lab to enhance the production of targeted polysaccharides.

\section{Authors' contributions}

FC conceived of the study and participated in its design and coordination and drafted the manuscript. T-LT and X-XC performed experiments and analyzed results and helped to draft the manuscript. W-JS, D-MH, JZ, YY, DW, and W-ML performed partial experiments and analyzed results. All authors read and approved the final manuscript.

\section{Author details}

${ }^{1}$ School of Food and Biological Engineering, Jiangsu University, Zhenjiang 212013, People's Republic of China. ${ }^{2}$ National Engineering Research Center of Edible Fungi, Shanghai Academy of Agricultural Sciences, Shanghai 201403, People's Republic of China. ${ }^{3}$ Jiangxi Provincial Engineering and Technology Center for Food Additives Bio-production, Dexing 334221, People's Republic of China.

\section{Acknowledgements \\ Not applicable.}

\section{Competing interests}

The authors declare that they have no competing interests.

\section{Availability of data and materials}

All data generated and materials used in the present study are presented in the paper.

\section{Consent for publication \\ Not applicable.}

\section{Ethics approval and consent to participate}

The strain Grifola frondosa GF 9801 was screened by Feng-Jie Cui and kept in our laboratory. The screening process complies with the corresponding guidelines of Jiangnan University.

\section{Funding}

This work was supported by funding from Natural Science Foundation of China (31771961), China Scholarship Council (201708320147), Shanghai Agriculture Applied Technology Development Program (2017, No. 9), China Postdoctoral Science special Foundation (2013T60648), Science \& Technology Platform Construction Program of Jiangxi Province.

\section{Publisher's Note}

Springer Nature remains neutral with regard to jurisdictional claims in published maps and institutional affiliations.

Received: 29 July 2017 Accepted: 15 December 2017

Published online: 06 January 2018

\section{References}

1. Rathore H, Prasad S, Sharma S. Mushroom nutraceuticals for improved nutrition and better human health: a review. PharmaNutrition. 2017;5(2):35-46.

2. Wang XM, Zhang J, Wu LH, Zhao YL, Li T, Li JQ, Wang YZ, Liu HG. A minireview of chemical composition and nutritional value of edible wildgrown mushroom from China. Food Chem. 2014;151(15):279-85.

3. Taofiq O, Martins A, Barreiro MF, Ferreira ICFR. Anti-inflammatory potential of mushroom extracts and isolated metabolites. Trends Food Sci Tech. 2016;50:193-210.

4. Li Q, Wang W, Zhu Y, Chen Y, Zhang WJ, Yu P, Mao GH, Zhao T, Feng WW, Yang LQ, Wu XY. Structural elucidation and antioxidant activity a novel Se-polysaccharide from Se-enriched Grifola frondosa. Carbohydr Polym. 2017;161(1):42-52.

5. Sharma SK, Gautam N. Chemical composition and antioxidant and antibacterial activities of cultured mycelia of four clavicipitaceous mushrooms (Ascomycetes) from the Indian Himalayas. Int J Med Mushrooms. 2017; 19(1):45-54

6. Chen L, Cheng WN, Zhang BB, Cheung PCK. Structural and thermal analysis of a hyper-branched exopolysaccharide produced by submerged fermentation of mushroom mycelium. RSC Adv. 2016;6(113):112260-8.

7. Li HZ, Zhang ZJ, Li MX, Li XJ, Sun ZW. Yield, size, nutritional value, and antioxidant activity of oyster mushrooms grown on perilla stalks. Saudi J Biol Sci. 2017;24(2):347-54.

8. Estrada AER, Jimenez-Gasco MM, Royse DJ. Improvement of yield of Pleurotus eryngii var. eryngii by substrate supplementation and use of a casing overlay. Bioresour Technol. 2009;100:5270-6.

9. Ryu JS, Kim MK, Im CH, Shin PG. Development of cultivation media for extending the shelf-life and improving yield of king oyster mushrooms (Pleurotus eryngii). Sci Hortic. 2015;193(22):121-6.

10. Liu XL, Zheng XQ, Qian PZ, Kopparapu NK, Deng YP, Nonaka M, Harada N. Purification and characterization of a novel fibrinolytic enzyme from culture supernatant of Pleurotus ostreatus. J Microbiol Biotechnol. 2014;24:245-53.

11. Zhang BZ, Inngjerdingen KT, Zou YF, Rise F, Michaelsen TE, Yan PS, Paulsen $\mathrm{BS}$. Characterisation and immunomodulating activities of exo-polysaccharides from submerged cultivation of Hypsizigus marmoreus. Food Chem. 2014;163:120-8.

12. Krull R, Wucherpfennig T, Esfandabadi ME, Walisko R, Melzer G, Hempel DC, Kampen I, Kwade A, Wittmann C. Characterization and control of fungal morphology for improved production performance in biotechnology. J Biotechnol. 2013;163:112-23.

13. Vetchinkina E, Kupryashina M, Gorshkov V, Ageeva M, Gogolev Y, Nikitina $\checkmark$. Alteration in the ultrastructural morphology of mycelial hyphae and the dynamics of transcriptional activity of lytic enzyme genes during basidiomycete morphogenesis. J Microbiol. 2017;55(4):280-8.

14. Ren XD, Xu YJ, Zeng X, Chen XS, Tang L, Mao ZG. Microparticle-enhanced production of $\varepsilon$-poly-L-lysine in fed-batch fermentation. RSC Adv. 2015;5:82138-43.

15. Fazenda ML, Harvey LM, McNeil B. Effects of dissolved oxygen on fungal morphology and process rheology during fed-batch processing of Ganoderma lucidum. J Microbiol Biotechnol. 2010;20(4):844-51.

16. Cui FJ, Chen XX, Liu WM, Sun WJ, Huo SH, Yang Y. Control of Grifola frondosa morphology by agitation and aeration for improving mycelia and exo-polymer production. Appl Biochem Biotech. 2016;179(3):459-73.

17. Wucherpfennig T, Hestler T, Krull R. Morphology engineering-osmolality and its effect on Aspergillus niger morphology and productivity. Microb Cell Fact. 2011;10:58. 
18. Antecka A, Blatkiewic M, Bizukojc M, Ledakowicz S. Morphology engineering of basidiomycetes for improved laccase biosynthesis. Biotechnol Lett. 2016;38:667-72.

19. Kaup BA, Ehrich K, Pescheck M, Schrader J. Microparticle-enhanced cultivation of filamentous microorganisms: increased chloroperoxidase formation by Caldariomyces fumago as an example. Biotechnol Bioeng. 2008;99:491-8.

20. Driouch $\mathrm{H}$, Sommer B, Wittmann C. Morphology engineering of Aspergillus niger for improved enzyme production. Biotechnol Bioeng. 2010;105:1058-68.

21. Cui FJ, Tao WY, Xu ZH, Guo WJ, Xu HY, Ao ZH, Jin J, Wei YQ. Structural analysis of anti-tumor heteropolysaccharide GFPS1b from the cultured mycelia of Grifola frondosa GF9801. Bioresour Technol. 2007;98:395-401.

22. Masuda Y, Nakayama Y, Tanaka A, Naito K, Konishi M. Antitumor activity of orally administered maitake a-glucan by stimulating antitumor immune response in murine tumor. PLoS ONE. 2017;12(3):e0173621.

23. Wu CY, Wu TX. Effect of the main ingredients of Rhizoma gastrodiae on mycelial biomass and exopolysaccharide productions by submerged culture of Grifola frondosa. Int J Food Sci Tech. 2015;50(8):1726-30.

24. Cui FJ, Li Y, Xu ZH, Xu HY, Sun K, Tao WY. Optimization of the medium composition for production of mycelial biomass andexo-polymer by Grifola frondosa GF9801 using response surface methodology. Bioresour Technol. 2006;97:1209-16.

25. Riley GL, Tucke KG, Paul GC, Thomas CR. Effect of biomass concentration and mycelial morphology on fermentation broth rheology. Biotechnol Bioeng. 2000;68:160-72.

26. Sluiter A, Hames B, Ruiz R, Scarlata C, Sluiter J, Templeton D. Determination of structural carbohydrates and lignin in biomass. Lab Analyt Proced. 2008;1617:1-6.

27. Zhu ZY, Liu XC, Dong FY, Guo MZ, Wang XT, Wang Z, Zhang YM. Influence of fermentation conditions on polysaccharide production and the activities of enzymes involved in the polysaccharide synthesis of Cordyceps militaris. Appl Microbiol Biotechnol. 2016;100:3909-21.

28. Peng L, Qiao SH, Xu ZH, Guan F, Ding ZY, Gu ZH, Zhang L, Shi GY. Effects of culture conditions on monosaccharide composition of Ganoderma lucidum exopolysaccharide and on activities of related enzymes. Carbohyd Polym. 2015;133:104-9.

29. Bradford MM. A rapid and sensitive method for the quantitation of microgram quantities of protein utilizing the principle of protein-dye binding. Anal Biochem. 1976;72(1-2):248-54
30. Kossen NWF. The morphology of filamentous fungi. Adv Biochem Eng Biotechnol. 2000;70:1-33.

31. Chen XX, Yang Y, Cui FJ, Sun WJ, Liu WM. Effect of aluminum oxide on Grifola frondosa mycelial biomass, pellet diameter and polysaccharide production. Acta Edible Fungi. 2016;23(1):42-6 (In Chinese).

32. Gonciarz J, Bizukojc M. Adding talc microparticles to Aspergillus terreus ATCC 20542 preculture decreases fungal pellet size and improves lovastatin production. Eng Life Sci. 2014;14(2):190-200.

33. Driouch $H$, Hänsch $R$, Wucherpfennig T, Krull R, Wittmann C. Improved enzyme production by bio-pellets of Aspergillus niger: targeted morphology engineering using titanate microparticles. Biotechnol Bioeng. 2012;109(2):462-71.

34. Bellou S, Makri A, Triantaphyllidou IE, Papanikolaou S, Aggelis G. Morphological and metabolic shifts of Yarrowia lipolytica induced by alteration of the dissolved oxygen concentration in the growth environment. Microbiology. 2014;160:807-17.

35. Rehm BHA. Bacterial polymers: biosynthesis, modifications and applications. Nat Rev Microbiol. 2010;8:578-92.

36. Yi W, Liu XW, Li YH, Li JJ, Xia CF, Zhou GY, Zhang WP, Zhao W, Chen X, Wang PG. Remodeling bacterial polysaccharides by metabolic pathway engineering. Nat Acad Sci USA. 2009;106(11):4207-12.

37. Li MJ, Chen TX, Gao T, Miao ZG, Jiang AL, Shi L, Ren A, Zhao MW. UDPglucose pyrophosphorylase influences polysaccharide synthesis, cell wall components, and hyphal branching in Ganoderma lucidum via regulation of the balance between glucose-1-phosphate and UDP-glucose. Fungal Genet Biol. 2015;82:251-63.

38. Tenhaken $\mathrm{R}$, Thulke $\mathrm{O}$. Cloning of an enzyme that synthesizes a key nucleotide-sugar precursor of hemicellulose biosynthesis from soybean: UDP-glucose dehydrogenase. Plant Physiol. 1996;112(3):1127-34.

39. Szumilo T, Drake RR, York JL, Elbein AD. GDP-mannose pyrophosphorylase. Purification to homogeneity, properties, and utilization to prepare photoaffinity analogs. J Biol Chem. 1993;268(24):17943-50.

40. El-Ganiny AM, Sheoran I, Sanders DA, Kaminskyj SG. Aspergillus nidulans UDP-glucose-4-epimerase UgeA has multiple roles in wall architecture, hyphal morphogenesis, and asexual development. Fungal Genet Biol. 2010;47(7):629-35.

\section{Submit your next manuscript to BioMed Central and we will help you at every step:}

- We accept pre-submission inquiries

- Our selector tool helps you to find the most relevant journal

- We provide round the clock customer support

- Convenient online submission

- Thorough peer review

- Inclusion in PubMed and all major indexing services

- Maximum visibility for your research

Submit your manuscript at www.biomedcentral.com/submit
() Biomed Central 